IFN Working Paper No. 924, 2012

\title{
Labor Market Conditions and Social Insurance in China
}

Johanna Rickne 


\title{
Labor market conditions and social insurance in China
}

\author{
Johanna Rickne
}

\begin{abstract}
Fifteen years after the introduction of highly ambitious social insurance programs for urban Chinese workers, a large number of them remain un-insured. This paper examines the relationship between labor market conditions and social insurance participation among industrial firms in the pre-crisis years of 2000-2007. I find that increased labor tightness over this period was a quantitatively important driver of participation. Comparing different segments of the labor market, stronger response to tightness is found in sectors with the largest shares of uninsured: private firms, those with a larger share of low-educated workers, and those without labor unions. Increased tightness in the years ahead can therefore be expected to aid policy makers in social insurance implementation and in combating insurance inequality.
\end{abstract}

JEL: J64, J65, D21

Keywords: social insurance, employer participation, labor market tightness, People's Republic of China

\footnotetext{
${ }^{1}$ Research Institute of Industrial Economics (IFN), P.O. Box 55665, SE-10215, Stockholm, Sweden; Email: <johanna.rickne@ifn.se>. The author gratefully acknowledges helpful comments from Bertil Holmlund, Lina Song, Björn Gustavsson, Per-Anders Edin, Fredrik Sjöholm, Johan Lyhagen, Olle Folke, Tor Eriksson and seminar participants at SNEE Conference 2010, Uppsala University, Stockholm School of Economics China Center (CERC), and CEA (Europe/UK). Dang Rui and Yulian Xu provided excellent research assistance, and Dina Neiman provided excellent editorial support. Financial support from the Marianne and Marcus Wallenberg Foundation, and the Ragnar Söderberg Foundation, is gratefully acknowledged.
} 


\section{Introduction}

The dramatic overhaul of China's social insurance system is a major component of the country's ongoing economic transition. In the late 1990s, the so-called "iron rice bowl" of the urban planned economy was broken as workers in State-Owned Firms were no longer guaranteed life-time employment and income protection from illness and old age. Managers were given greater flexibility in hiring and firing decisions and new social insurance programs were created. These new programs required workplaces in all sectors, not just the statecontrolled, to make contributions on behalf of their workers.

To date, extending insurance coverage remains a political priority (Xinhua, 2012-0603). Besides improving worker welfare, a successful transition to the new system is also expected to provide the wider economic benefit of reducing precautionary savings and spurring domestic demand (Chamon and Prasad, 2010; Feng et al., 2011). ${ }^{2}$ Achieving such inclusive growth is the focal policy for China's economic transition over the next Five Year Plan (Du, 2011).

Few studies have examined the determinants of social insurance participation among Chinese firms, and evidence is particularly scarce regarding the relationship between firm behavior and market developments. ${ }^{3}$ As China moves toward the Lewis Turning Point - a topic much debated in the research literature ${ }^{4}$ - labor shortages, growing wages and demand for social inclusion arise as joint challenges (Du, 2011). Understanding if, how, and which firms respond to these developments can provide useful insights about the Chinese labor market regarding the highly relevant policy area of social insurance.

Using a simple theoretical framework I argue that firms respond to tighter labor markets by increased participation in social insurance programs. When unemployment is high and the number of vacant jobs is large, competition for labor becomes fiercer and firms are

\footnotetext{
${ }^{2}$ Private savings as a share of disposable income has consistently risen since the second half of the 1990s, reaching 28\% in 2008 (Prasad, 2009). From a macroeconomic perspective, these increasing savings have been a main contributor to the declining share of consumption in China's GDP (Lardy, 2007).

${ }^{3}$ Nyland et al. (2011) report evidence from an interview study of six firms, finding cost containment to be the major motive for evasion, and recruitment of skilled labor to be a major driver of participation. Yao and Zhong (2010) and Lu et al. (2010) show that unionization of firms is conducive to improved social insurance coverage of the workforce.

${ }_{4}^{4}$ The subject to two recent special issues (China Economic Journal, Volume 3 Issue 2 of 2010, and China Economic Review, forthcoming), the theory states that as poor countries develop, rural labor with low demands on work compensation flows to the cities. When this source of low-wage workers eventually tapers off, wages increase and the country moves to the next development stage as the dual (rural and urban) economies merge. In the Chinese case, there is substantial disagreement on the causes of rising wages as pertaining to either a real shortage of rural labor or a "manufactured" shortage based on selective migration quotas based on the household registration system called hukou (Wang, 2005; Knight and Song, 2005).
} 
incentivized to increase their attractiveness by offering insurances as part of their compensation package.

To test this basic hypothesis I draw upon an unbalanced panel of firms for 2000-2007, a dataset that together represents nearly 90 percent of China's industrial output and two thirds of industrial employment. This data comes from annual firm reports collected by the National Bureau of statistics and includes expenditure data for social insurance, information that can be used to infer program participation. Conveniently, the time period spans the years following the introduction of the three major social insurance programs, namely Pension (1997), Medical (1998) and Unemployment insurance (1999), but does not include the labor market disruptions of the financial crisis starting in $2008 .^{5}$

The empirical analysis relates firms' insurance participation, measured as non-zero annual expenditures, to the degree of tightness on the regional ${ }^{6}$ labor market, calculated from unemployment and vacancy data reported by local labor offices and aggregated to the regional level in China's Statistical Yearbook. The regression results show support for the hypothesis that firms respond to the market signal by offering insurance. Relating the estimated effect to the trends of increased tightness over the period, almost half of the increase in participation can be accounted for by this factor. Notably, these results should, however, not be interpreted as an equally important impact on the share of workers covered because of segmentation in coverage within the firm (Nyland et al., 2011; Lu et al., 2010). Non-zero payments nevertheless represent an important first step of participation, and the statistical relationship between this first step and labor scarcity is highly robust to, among other things, including firm fixed effects and restricting the sample to control for measurement error in the main dependent and independent variables.

A striking point of policy relevance of the main result is that increased labor market tightness has aided policy makers in the process of implementing social insurance in the urban industrial sector. In an attempt to further explore this relationship, I divide firms according to characteristics shown by previous literature to capture important dimensions of labor market segmentation: ownership, workforce education level, and unionization.

Descriptive evidence on insurance participation across firm segments mirrors previous evidence on wages, showing higher participation rates in the "upper segments": firms with state- and foreign ownership, those with highly-educated workers, and having an in-house

\footnotetext{
${ }^{5}$ The period of study thus predates the establishment of the Bureau of Human Resources and Social Security in 2008 and the introduction of China's first national law on social insurance in 2011. These institutional developments further underline the political relevance of the transition of the social insurance system.

${ }^{6}$ The term region is used for Chinas 22 provinces, 5 Autonomous Regions, and 4 self-governing municipalities.
} 
branch of China's only legal union. An, arguably, more surprising finding is that the response to labor market tightness is traced to the lower segment. In other words, tightness impacted on the sectors with the largest share of uninsured workers the most, meaning that it triggered a convergence in regulatory compliance (and inequality) between the sectors.

The result that private firms with low-educated workers and lacking labor unions responded more strongly to labor scarcity is most likely a consequence of greater pressure from labor market tightness in these segments. Under equal pressure, the analysis could have been expected to show the opposite result as a reflection of greater recruitment costs for highskilled workers. An alternative interpretation could also be that protected industrial sectors remain inflexible in terms of compensation patterns and less sensitive to labor market signals due to soft budget constraints and institutional relationships with the government.

The remainder of the paper is organized as follows: Section 2 outlines the evolution of China's unemployment insurance, surveys the literature on determinants of firm participation, and develops a simple theoretical model relating participation to labor market conditions. Section 3 discusses the data and variables with special attention to the regional measure of labor market tightness and approximation of insurance participation. Section 4 outlines the estimation method and baseline results. Section 5 diversifies the analysis across the dimensions of firm ownership, workforce education level, and firm unionization. Section 6 concludes.

\section{Social insurance reform and evasion}

This section briefly summarizes China's social insurance reforms as applied to the urban industrial sector and outlines existing research on the subject of insurance participation among firms.

\subsection{Social insurance overhaul}

Shortly after the proclamation of the People's Republic of China in 1949 an ambitious set of entitlements for the urban workforce was formulated. The so-called "iron rice bowl" provided workers in Chinese urban enterprises with a number of non-wage benefits under the 
umbrella term Labor Insurance Scheme (LIS). ${ }^{7}$ Besides its three main components: health insurance, injured-worker insurance and old-age insurance, many workers also benefitted from insurance for sickness, invalidity, maternity and death (Tang and Ngan, 2001).

Overhaul of the workplace-based social insurance system has been a key institutional transition on China's path to a (more) capitalist economy. These reforms were triggered by two main factors. Over the course of the reform period, the growing number of workers in the private sector lacked formal income protection because the LIS only applied to the statecontrolled sector. Simultaneously, State Owned Enterprises (SOEs) faced a growing competitive disadvantage vis-à-vis private firms due to rapidly expanding costs from retired and laid-off workers each of whom continued to be the financial responsibility of the SOE.

By replacing the LIS with separate and reformed insurance programs, China has aimed at overcoming these problems. Importantly, the new schemes apply equally to all urban firms. This risk pooling across sectors has improved SOE competitiveness by transferring accumulated liabilities from the individual firms, under the old program, to the social pool under the new (i.e. from the SOEs to the private sector).

The new insurance programs place a large responsibility with the employer, requiring registration for participation and regular contributions to be made, both on the part of the workers (deducted from wages) and of the firm (as a share of payroll). Contributions need to be made over a number of years to grant eligibility for benefits, 15 years for the pension program, and at least one year for the unemployment insurance. ${ }^{8}$

Table 1 lists each of the main social insurance programs by the year that they regulatory frameworks were first introduced. It also summarizes the payment rates for Beijing and Shanghai. According to the US Social Security Administration, the total payments for social security in China's urban areas amount to 29 percent of payroll for the firm and 11 percent of wages for the worker. This makes China's system one of the world's costliest in terms of the relative rise in unit labor cost stemming from social insurance contributions. In comparison, US employers pay 9.7 percent in social insurance, German employers pay 19.61, and Swedish pay 23.43 percent (U.S. SSA 2010, various regional issues).

As illustrated in Table 1 payment rates vary between regions (and they may also vary between prefecture cities within regions). However, urban firms can also hire rural workers, i.e. those with a rural hukou who lack the right of permanent residence and employment in urban areas. While a few localities have created uniform programs for rural and urban

\footnotetext{
${ }^{7}$ From its setup in 1951, rural areas were excluded from the LIS (Hussain, 1994).

81 to 5 years of contributions merits 12 months of benefits, 5 to 10 years merits 18 months, and more than ten years gives up to 24 months of benefits.
} 
workers (such as Shenzhen), the majority continue to separate between them. In the latter case much less generous provisions, and lower costs, apply to the segment of rural workers (such as Shanghai) (for an overview of regulatory frameworks underpinning this highly fragmented system, see Zhang et al., 2010). Moreover, insurance payments were until recently not transferrable between regions, a provision that is being instituted based on the Social Insurance law of 2010.

Table 1. Payment rates for China's urban social insurance programs, Beijing and Shanghai.

\begin{tabular}{lcccc}
\hline & \multicolumn{2}{c}{ Beijing } & \multicolumn{2}{c}{ Shanghai } \\
\cline { 2 - 5 } & $\begin{array}{c}\text { Employer } \\
\text { (\% of payroll) }\end{array}$ & $\begin{array}{c}\text { Employee } \\
\text { (\% of wage) }\end{array}$ & $\begin{array}{c}\text { Employer } \\
\text { (\% of payroll) }\end{array}$ & $\begin{array}{c}\text { Employee } \\
\text { (\% of wage) }\end{array}$ \\
\hline Pension insurance (1997) & 20 & 8 & 22 & 8 \\
Medical insurance (1998) & 10 & 2 & 12 & 2 \\
Unemployment insurance (1999) & 1 & 0.2 & 1.7 & 1 \\
Occupational injury insurance (1996) & 0.3 & 0 & 0.5 & 0 \\
Maternity insurance (1994) & 0.8 & 0 & 0.8 & 0 \\
Total (\%) & 32.1 & 10.2 & 37 & 11
\end{tabular}

Notes: for details on program regulations, including the structure and size of benefits, see China's Social Security White Paper (2004) or U.S. SSA (2010).

\subsection{Determinants of participation: theory and previous literature}

There are not many studies that have considered the drivers of participation in social insurance among Chinese firms. There is also a lack of international literature because most developed countries have universal systems where firms do not make active decisions on participation.

Economic theory on regulatory compliance in general takes compliance cost as a starting point (Becker, 1968). This has also been the insight from the, rather scarce, studies on Chinese firms; because the program premiums are quite high, there is a lot to be saved by evading participation. Nyland et al. (2011) conduct interviews with human resource staff and managers, trade union staff members and senior management at eight firms, all of which considered social insurance to be a key factor in profitability. To contain costs, most firms implemented some stratification between different segments of the workforce. Hiring rural and/or migrant labor was an important route to lowering costs. Firms also weighed the risk and cost of being caught with evading participation (i.e. enforcement intensity and fines) against the need to make profits and be competitive. A similar concern is carried out by 
Vodopivec and Tong's (2008) in their analysis of the unemployment insurance. Evasion is seen as driven mainly by low costs of evasion: vague regulation, poor enforcement and small

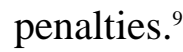

Nielsen and Smyth (2007) use audit data obtained from Shanghai's Bureau of Labor and Social Security (BOLSS) to contribute an important insight as to why compliance costs are high. If firms can shift the cost of insurance over to the worker in the form of a lower wage, participation is of course cost-neutral. Chinese firms are however found to shift a very small proportion of the costs in that way, 9.1 percent in 2002 and 33.8 percent in $2003-$ figures much lower than those found in other countries. In their discussion of this result the authors mention the fact that some firms operate on minimum wages and simply could not lower wages further. ${ }^{10}$

Two main mechanisms are highlighted in the earlier literature as aiding insurance coverage for workers. The first is unionization, echoing the evidence for US firms in earlier studies (for example Rice, 1966; Woodbury, 1983). Yao and Zhong (2010) analyze a crosssection of 1,500 industrial firms and find a positive correlation between unionization and social insurance coverage of workers. The mechanism behind this result, they argue, is that unions bargain for more permanent labor contracts which in turn entitle workers to insurance. In a similar study of 4,000 firm surveyed in 2006, Lu et al. (2010) also find a positive correlation between the share of workers with social insurance and the existence of an inhouse union (but, perhaps curiously, no correlation is found between wages and unionization). They argue that the results illustrate a new role of the Chinese union as bargainer for worker rights.

The second mechanism, and the one most relevant to this study, is use of social insurance as a recruitment tool. In Nyland et al.'s (2011) interview study, the majority of the firms point out the fact that insurance is used to recruit labor, in particular highly educated workers. This finding aligns with the economic literature that has analyzed non-wage compensation in US firms. Firms use attractive social insurance packages to recruit, and

\footnotetext{
${ }^{9}$ Nielsen and Smyth (2007) provide a description of the enforcement and penalty structure in Shanghai in the early 2000s. Non-compliant firms were identified by means of annually conducted random audits of about 2-5\% of the total population of firms. If found to be in arrears, firms were first given a 15 day period to make up their payments. After this period, interest of $0.02 \%$ was added to the amount in arrears, and after 10 months, the authorities could mortgage firm property to cover the debt. A hotline was also available for employee whistle blowing on firm evasion, but this tool was judged as inefficient by the managers interviewed in the study.

${ }^{10}$ The descriptive statistics of the official audit data sample, however, cast some doubt on the authors' claim of representativeness of Shanghai's firm population. The proportion of firms meeting their payment obligations tripled from 18 percent in 2002 to 65 percent in 2003, and the ownership distribution of the sample shifted dramatically between the two years. The share of SOEs in the sample declined from $39 \%$ in 2002 to $12 \%$ in 2003 and the share of private firms dropped from $10 \%$ to $4 \%$, while the share of foreign-invested firms rose from $33 \%$ to $43 \%$
} 
retain, labor, especially skilled labor for which turnover costs are higher (Rice, 1966; Mabry, 1973; Long and Scott, 1982; Woodbury, 1983).

\subsection{A simple model of the firm's participation choice}

This section formalizes the argument that social insurance is used as a recruitment tool, and connects it to the labor market conditions facing the firm. In essence, a tighter labor market is argued to increase recruitment costs and thereby incentivize participation in the programs.

Consider a firm operating in a fictional labor market where local labor market conditions influence the speed of recruitment. Employment, $N_{i}$, in firm $i$ changes according to

$$
\partial N_{i} / \partial t=H_{i}-\phi N_{i}
$$

where $H_{i}$ is the flow of hires and $\phi$ the exogenous separation rate. The hiring function takes the form

$$
H_{i}=q V_{i}
$$

where $q$ is the rate at which vacancies are filled and $V_{i}$ is the number of vacancies. The rate at which vacancies are filled depends on local labor market characteristics, such as the local vacancy rate $(v)$ and the local unemployment rate $(u)$. It also depends on compensation to workers, such as wages and social insurance benefits.

Assume that the firm is a wage taker but that it can influence recruitment by provision of social insurance. Suppose that the firm's recruitment function is given by

$$
q=a(b) \theta^{-\eta}
$$

where $\theta=v / u$ is a measure of labor market tightness, $a(b)$ captures a positive relationship between recruitment intensity $(a)$ and social insurance benefits $(b)$ with $a^{\prime}(b)>0$ and $a^{\prime \prime}(b)<0$, and $\eta$ is a positive constant. The tighter the local labor market, the more difficult it is for the firm to fill a vacancy, but the more generous benefits the firm offers, the easier it is to fill the vacancy. 
The firm's profit function is

$$
\pi_{i}=A N_{i}^{\alpha}-w N_{i}-T(b) N_{i}-c V_{i} \quad \alpha<1,
$$

where $w$ is the wage rate, $T$ is a tax function that is increasing in social insurance provision, $T$ '(b) $>0$ and $c$ is the cost of recruitment. The firm ignores discounting, takes the wage as given and chooses $N_{i}$ and $V_{i}$ to maximize steady-state profits, recognizing the hiring constraint $a \theta^{-\eta} V_{i}=\phi N_{i}$. Thus,

$$
\pi_{i}=A N_{i}^{\alpha}-w N_{i}-\left[T(b)+\frac{\phi c \theta^{\eta}}{a(b)}\right] N_{i}
$$

and the first-order conditions for a maximum are

$$
\begin{gathered}
N_{i}: \quad \alpha A N_{i}^{\alpha-1}-w-T(b)-\frac{\phi c \theta^{\eta}}{a(b)}=0, \\
b: \quad-T^{\prime}(b)+\frac{\phi c \theta^{\eta} a^{\prime}(b)}{[a(b)]^{2}}=0,
\end{gathered}
$$

which determine $N_{i}$ and $\mathrm{b}$ as functions of the wage and labor market tightness. Provided that an interior maximum exists, it is straightforward to establish that $\partial b / \partial \theta>0$. The marginal gain to the firm of (increased) insurance provision is greater the tighter the labor market is. To understand this implication, note that the cost of a vacancy is

$$
c V_{i}=\frac{N_{i} \phi c \theta^{\eta}}{a(b)}
$$

which means that the tighter the labor market is, the greater is the cost-reducing effect of an increase in $b$.

Note that the simplified model only assumes that an unemployed worker prefers a job with social insurance to a job without insurance. The potentially positive relationship between 
a tightened labor supply and the bargaining position of already hired workers is, meanwhile, not formally modeled. ${ }^{11}$ As we will see, the empirical evidence does not indicate a strong role for this channel, but its exclusion should be kept in mind when interpreting the results.

\section{Data, variables, and descriptive statistics}

\subsection{NBS annual survey of industrial enterprises}

I use data from annual accounting reports collected by the National Bureau of Statistics over the 2000-2007 period. This data is sometimes referred to as the "above-size" sample of firms and forms the basis for the Industrial Market Yearbook and the Industry Chapter in China's Statistical Yearbook. ${ }^{12}$ It includes all state-owned industrial firms and all other firms with annual sales exceeding 5 million RMB (about $\$ 650,000$ ) - workplaces that together account for more than 90 percent of total industrial output and 70 percent of employment. For 2004 the data includes an expanded set of variables collected in the Firm Census conducted in that year, including unionization and the education level of each worker.

The firm survey contains two social insurance items: i) the combined expenditures on the unemployment insurance and Labor Insurance, available for the full 2000-2007 period; and ii) the combined expenditures for the medical and pension insurances, available from 2004 to 2007. The dataset contains 1,289,980 firm-year observations for urban firms, and 540,006 observations for rural firms, where the latter is defined as being under the administrative subordination of a township, village, or residence committee.

Observations with negative, zero or missing values for the regression variables of insurance expenditures, employment, or sales are dropped (19,213 firm-year observations). To control for the potential influence of outliers, I also delete observations in the one percent lower and upper tail for each of the yearly distributions of employment (40,390 observations)

\footnotetext{
${ }^{11}$ The little empirical evidence available supports the assumption of weak demand for insurance among employees. The insurance system has suffered from poor legitimacy because of financial difficulties, administrative challenges, unclear rules concerning benefits, and geographical fragmentation. Anecdotal evidence gathered from interviews with firm managers (Sha, 2007; Jiang and $\mathrm{Si}, 2006$ ) suggested that workers (for the reason of uncertainty associated with the future benefits from coverage, as well as with the transferability of one's accumulated account balance across regions) preferred wage compensation over nonwage benefits in the form of social insurance. In Nyland et al's (2011) interviews, worker demand was not mentioned by firms as a factor in their insurance decision. The motive for providing cover to more educated workers was not described in terms of a greater demand from this group, but rather to reduce turnover costs by providing them with benefits that were not transferred between workplaces.

${ }^{12}$ Chinese industrial statistics are divided into two basic groups, above and below designated size. Firms with annual sales above $\$ 650000$ are counted into the former group, and are obliged to submit regular accounting reports to the NBS. Using the 2004 Industrial Census as a benchmark, the above size sample represents 31 percent of the total number of firms but covers over 90 percent of total industrial output, sales, exports, and value of fixed assets, and about 70 percent of employment.
} 
and sales (another 31,544 observations). In the analysis of each of the social insurance variables I exclude the upper one percent tail of the ratio of that particular insurance expenditure to firm employment. Adjustments are also made for the 2003 re-classification of industrial sectors. ${ }^{13}$ Finally, firm identification codes are adjusted to account for changes associated with restructuring, mergers or acquisitions. ${ }^{14}$

\subsection{Insurance participation}

I measure insurance participation as a dichotomous variable taking the value one for firms that report non-zero insurance expenditures. This definition requires some caution in the interpretation of the results. First, it is incorrect to interpret non-zero expenditures as insurance coverage for all employees. Firms may under comply with their required payment amount (Nielsen and Smyth, 2007) or use strategies of internal segmentation by contract types to cut insurance costs (Nyland et al., 2011). In the 2006 cross section of 4,000 private firms studied by Lu et al. (2006) the average firm provided only one fourth of the employees with medical and pension insurance respectively, and only one fifth of the employees had unemployment insurance. Such under-compliance should be taken into account when interpreting the results, but this does not belie the important distinction between having zero and non-zero expenditures. It means that the firm registered for participation and is making contributions, which is an important first step in the implementation process of the social insurance programs. Moreover, the results of the paper are largely robust to excluding firms for which the total amount of contributions as a ratio of the total wage-bill is less than 80 percent of the national average for insurance contributions.

The participation variable could contain measurement error if firms erroneously report nonzero expenditures to signal rule compliance or to avoid taxation (because unlike wages, social insurance contributions are not taxed) (Banister, 2005). Arguably, this type of over-statement of insurance payments is considerably less problematic for the zero-or-one payment distinction compared to a measure of within-firm variation in generosity. In order to

\footnotetext{
${ }^{13}$ The industrial classification system GB/T 4754-2002 replaced the GB/T 4754-1994 system. 2-digit sectors are adjusted as follows: i) drop the division 'wage recycling' prior to 2003 , ii) add the 'weapons and ammunition manufacturing' category to the 'special equipment manufacturing' category after 2003, iii) add 'Bamboo and Lumber' to 'Timber' category for 2003 onward. A basic concordance table shows only slight changes of products between new and old 2-digit divisions on the 3-digit level.

${ }^{14}$ Matching of firms to find the broken ID-links is based on background variables such as telephone number, industrial sector, zip code etc, and follows the coding practice provided in the online appendix of Brandt et al. (2012). Codes are adjusted for about $2 \%$ of the firms.
} 
start making payments the employer needs to register with the relevant authorities to set up accounts for the employees which offers a greater hurdle for misreporting.

Another important question of interpretation is that both dependent variables measure combined expenditures on two items. In the case of the unemployment insurance, it also includes costs for the labor insurance, a program that existed exclusively in State-controlled firms (SOEs and Collective Owned Enterprises, COEs) but which was phased out during the late 1990s. Because not all firms complied swiftly with the change in regulations, a cleaner measure of participation in the relevant insurance programs (note that the LIS included pension and medical endowments) is obtained by dropping firms where expenditures on the combined item exceeds the regional payment level for the unemployment insurance. ${ }^{15}$ Removing these firms only marginally affects the results, as will be shown in the robustness checks below.

Combined expenditures are also reported for the pension and medial insurances. This means, of course, that regression results must be interpreted as the correlation between labor market tightness and participation in at least one of those programs.

Figure 1 shows the distributions of regional participation for each of the two social insurance variables over time (for urban firms only). We can note substantial variation both in the geographical and time dimensions. A closer examination of the specific provincial rates (not reported) reveals a strong correlation to the regional development level. Higher rates exist in more developed localities, such as Beijing, Shanghai and Fujian, while poorer regions like Tibet or Gansu lie below the average.
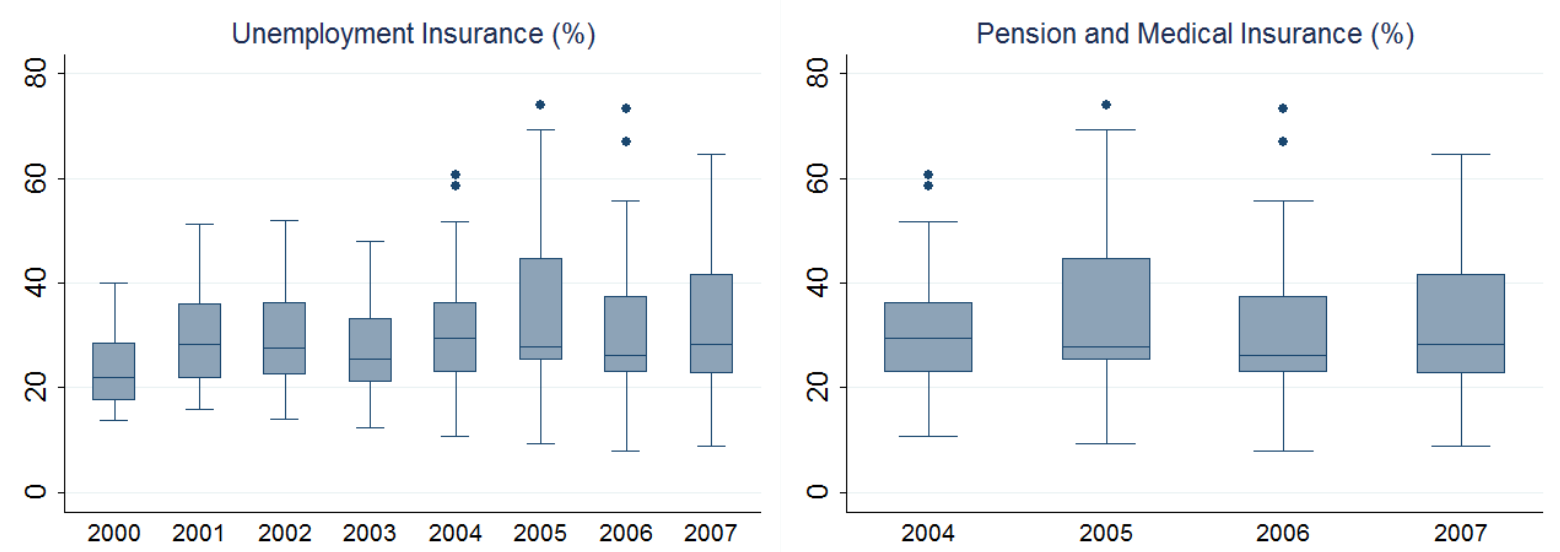

Figure 1: Distribution of provincial participation rates for the unemployment insurance, and pensions and medical insurances, for above-size industrial firms.

\footnotetext{
${ }^{15}$ The payment rate is set on the regional level and rarely deviates from the state's guideline of $2 \%$ of the worker's average annual wage (as indicated on the homepages on provincial governments).
} 


\subsection{Descriptive statistics}

After cleaning the data, 1,050,923 firm-year observations remain in the sample of urban firms, which are used for the main analysis. Table 2 below reports some descriptive statistics for these firms. We can note that participation in the social insurance programs increased over time, while average firm size and market share decreased.

The relatively larger number of observations in the early years reflects not only industrial growth but also that some of the sample restrictions predominantly remove firms in the earlier years. In particular, the exclusion of firms with a high ratio of combined unemployment and labor insurance expenditures to payroll removes firms which had not yet replaced labor insurance with unemployment insurance. Moreover, rural registration of firms was comparatively more common in the earlier years.

Table 2: Summary statistics for urban industrial firms, 2000-2007.

\begin{tabular}{lcccc}
\hline & 2000 & 2004 & 2007 & $\begin{array}{c}2001-2007 \\
\text { Average }\end{array}$ \\
\hline Unemployment insurance participation (\%) & 25 & 30 & 32 & 31 \\
Pension and medical insurance participation (\%) & & 55 & 60 & 58 \\
Number of employees & 245 & 175 & 170 & 187 \\
Market share & 1.6 & 0.5 & 0.4 & 0.6 \\
Number of observations & 27,975 & 191,867 & 231,923 & $1,050,923$ \\
\hline
\end{tabular}

\subsection{Labor market tightness}

Labor market tightness is measured as the ratio between the provincial unemployment and vacancy rates. This is computed by dividing the number of unemployed persons and the number of vacant jobs registered at labor offices by total employment (China's Statistical Yearbook, various issues). ${ }^{16}$

China's definition of unemployment follows the International Labor Organization and includes those who become jobless i) as a consequence of enterprise bankruptcies; ii) by having their contracts terminated or canceled; iii) by being dismissed; iv) by resigning; or v) after graduating and failing to find first-time employment. The reliability the official unemployment rate has however been the subject of some debate.

\footnotetext{
${ }^{16}$ In 2005, the OECD judged these labor offices to be a "decentralised and relatively well-equipped office network" numbering 26000 units in 2003 (OECD 2005, p. 18).
} 
Two main groups of workers have been excluded from the unemployment count, the so-called job-waiters (xiagang) a term used to describe the persons discharged from SOEs in the retrenchment programs of the 90s, and migrant workers. This could cause spurious regression results if the measurement error from excluded unemployed is correlated with labor market conditions. In the case of the job-waiters, there are unfortunately no regional statistics to allow a computation of the "true" unemployment rate in the style of, for example, Giles et al. $(2005)^{17}$. I instead use information on regional variation in the so-called binggui reform which merged the job-waiters with the unemployment system. Nine regions had completed this policy by the early 2000s, meaning that the job-waiters are included in the unemployment count (Vodopivec and Tong, 2008). ${ }^{18}$

The second source of measurement error in the unemployment rate is that workers with rural hukou are excluded from both the employment and the unemployment count. At least according to the official view, excluded migrant labor only marginally affects the unemployment statistic. This is because migrants self-select into employment and return to their rural hometowns when the urban labor market becomes tighter (Fox and Zhao, 2002). If migrants residing in urban areas nevertheless are under-counted in the unemployment statistic, the question becomes whether this measurement error could drive a spurious correlation between labor market tightness and social insurance participation. Assuming that the share of uncounted jobless migrants (i.e. the downward bias on the unemployment rate) is proportional to the share of employed migrants in the region, this seems unlikely. As many studies have shown, migrant labor is less likely to be covered by social insurance than other segments of the workforce (for example Lu and Song, 2006; Nyland et al., 2011; Giles et al., 2011).

Shifting focus to the vacancy rate, there are also a couple of things to note. Upward bias in this figure could result if a job is not filled within a certain timeframe in which case it may be posted again and hence counted twice. Some firms may also register their advertisement with several agencies which will also over-estimate the number vacant positions.

Figure 2 show the distributions of the provincial unemployment and vacancy over time, and Figure 3 shows the ratio of these two measures (v/u), that is, the labor market

\footnotetext{
${ }^{17}$ This method has also been criticized based on the argument that job-waiters in fact have jobs. Such 'hidden employment' may also exist in the unemployment numbers, in particular because of low unemployment insurance benefit levels and weak enforcement of eligibility criteria.

${ }^{18}$ Namely Beijing, Tianjin, Shanghai, Jiangsu, Zhejiang, Guangdong, Fujian, Shandong and Liaoning. In 2005, a total of 20 regions had completed the binggui reform and the number of job-waiters had fallen from its peak of 7 million in 1991 to 200,000 by 2005 .
} 
tightness measure. Tightness increased gradually during the period, with the median across regions doubling from 2.43 in 2000 to 4.88 in 2007. This development was driven by an increasing vacancy rate (from $7.9 \%$ to $19.6 \%$ ), while unemployment increased over the first sample years and dropped somewhat during the latter. Increasing labor market tightness reflects the numerous accounts in the media of labor shortages for industrial firms before the onset of the financial crisis (for example, the Economist 2008-09-04; New York Times 200604-20)
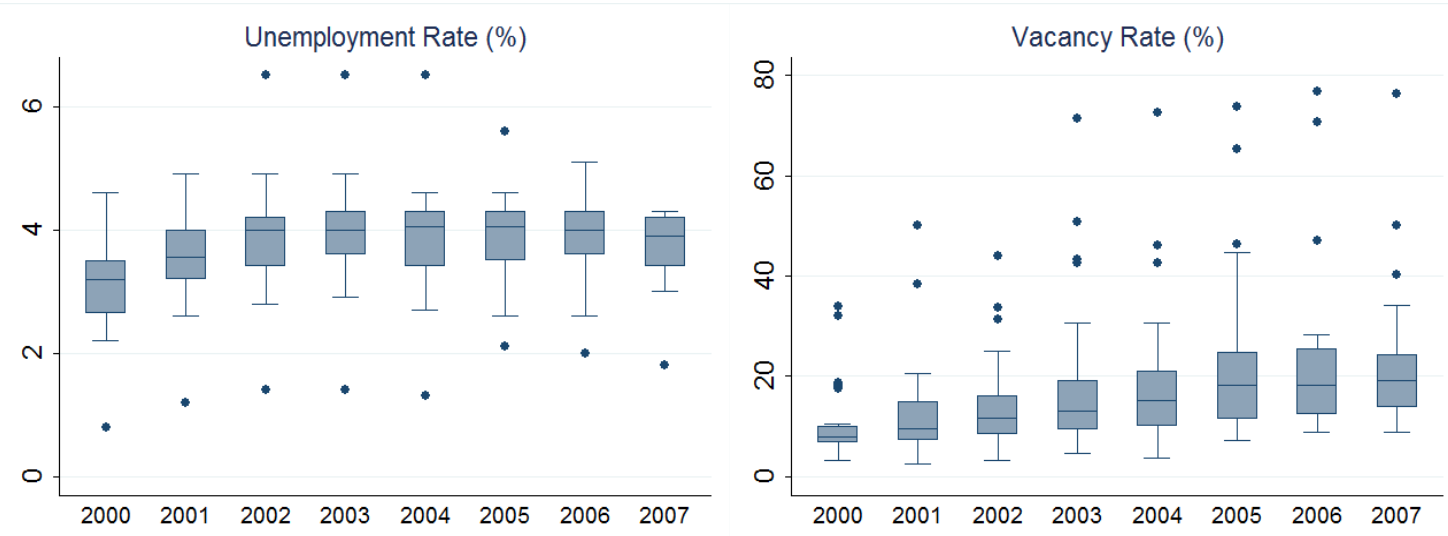

Figure 2: Distribution of regional unemployment and vacancy rates (\%) 2000-2007.

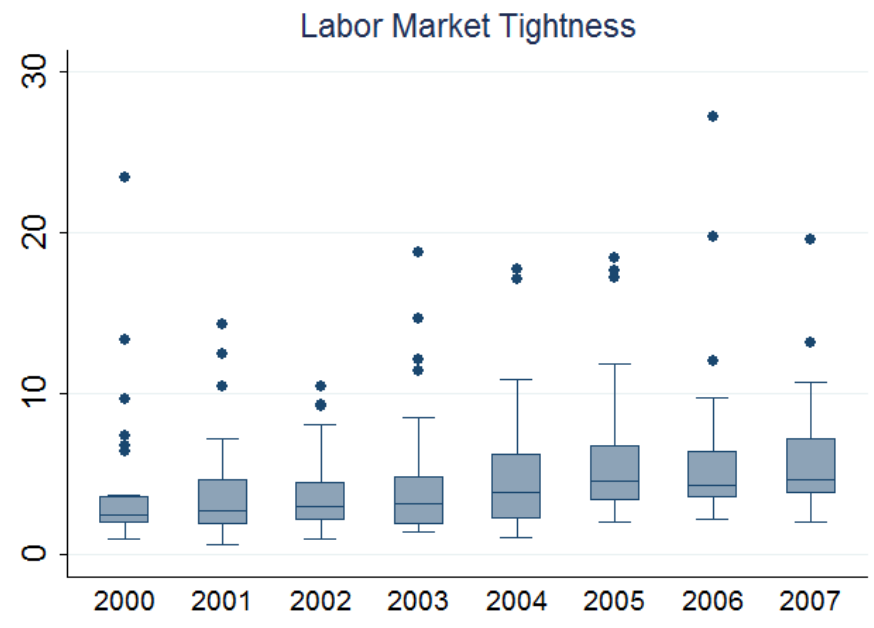

Figure 3: Distribution of regional labor market tightness rates (vacancies/unemployed).

Measuring labor market conditions on the regional level is problematic to the extent that firms may respond to the conditions on smaller labor markets which are not properly reflected by the regional aggregate. Unfortunately, research on labor mobility in China is scarce, and 
has mainly focused on the rural-urban segmentation rather than the mobility of urban workers. From the Population Census, we know that intra-regional migration is the most common relocation choice, accounting for two thirds of all migration in the 2000 and 2005 samples (Taylor, 2011). Among the intra-provincial moves recorded in 2005, rural-to-urban moves were about three times as common (57\%) as urban-to-urban (17\%). Nevertheless, the hukou system creates search costs for moves between cities in the same region because workers are separated from the zone of their hukou registration. ${ }^{19}$ Based on the intuition that the unemployment and vacancy figures are most accurate for the main regional employment hubs, robustness checks are used to ascertain that results are robust to including only firms located within the self-governing municipalities and prefecture capitals.

\section{Empirical specification and results}

\subsection{Specification}

The prediction of the theoretical model are tested by estimating the Equation

$$
P_{i, t}=\beta_{0}+\beta_{1} \theta_{r, t}+\beta_{2} S O E_{-} \text {share }_{r, t}+\beta_{3} M_{r, t}+\beta_{3} \ln L_{i, t}+\beta_{4} \mathbf{Z}_{c, t}^{\prime}+\gamma_{t}+\delta_{s}+\varepsilon_{i, t}
$$

where $P_{i, t}$ is a dichotomous variable for firm $i$ 's participation in either the unemployment insurance, or in the pension or medical insurances, in year $t$. The main coefficient of interest is $\beta_{1}$ which captures the effect of labor market tightness in region $r$ and period $t$ on this participation decision. Standard errors are clustered at the regional level to reflect the unit of observation for the labor market tightness variable. All estimations include year fixed effects $\gamma_{t}$ to account for time trends in the rate of insurance participation, and 2-digit industry level fixed effects $\delta_{s}$. OLS is used for the estimation for easy interpretation of the coefficients and to avoid biased estimators associated with the numerous fixed effects. To address heteroscedasticity in the linear probability model I use Eicker-Huber-White standard errors, and double-check the results for robustness to estimation by Probit.

Three control variables are included to account for factors that have been shown to drive social insurance provision of firms, and which may also be associated with tighter labor

\footnotetext{
19 Wang (2005) provides a thorough explanation of the complex system which administratively ties each individual to a specific city, town, or village. As a general rule, the institutional impediments to mobility, however, increase with distance and decrease with personal connectedness and education level.
} 
markets. The first is a measure of the degree of state sector dominance on the regional labor market, measured by the share of SOE employment in total employment ( $\left.S O E \_s h a r e\right)$. The institutional ties to the state makes this sector more likely to follow government regulations and also more likely to contribute to tight labor markets by hoarding labor (Nyland et al., 2011; Dong and $\mathrm{Xu}, 2009){ }^{20}$

The other two variables capture the size of the firm, $\log$ employment $\left(\ln L_{i, t}\right)$ and market power - a Herfindahl index calculated at the 3-digit product level by region $-\left(M_{r, t}\right)$. If firms in regions with tighter labor markets are larger and have greater market power, this could potentially introduce bias in the estimate on tightness. These firms are more likely to hold monopsony power and therefore be able to shift the cost burden of insurance to consumers or employees (Mares, 1997; 2003). Increased insurance provision could also stem from profit sharing when profits rise as a consequence of market power (c.f. Knight and Li, 2005). ${ }^{21}$ Protected and powerful firms are also likely to contribute to tighter labor markets by hoarding labor as they are subject to less competition (Dong and $\mathrm{Xu}, 2009$ ).

Finally, studies have noted that Chinese government officials in less geographically advantageous locations are more lenient regarding regulatory compliance for fear of triggering business closures and loss of jobs (Ma and Ortolano, 2000; Schwartz, 2003; Nyland et al., 2011). Because these locations are also likely to have less tight labor markets (due to the greater difficulties faced in attracting investment), I risk confusing this underlying geographical characteristic with labor market tightness as a driver of participation. Two control variables $\mathbf{Z}_{c, t}^{\prime}$ are included to measure the locality's attractiveness for commerce and industrial investment. They are i) the distance between each prefecture city and the closest of China's three large ports (Hong Kong, Tianjin or Shanghai) and, ii) the distance to the closest of China's 15 largest cities. ${ }^{22}$

\footnotetext{
${ }^{20}$ Nyland et al. (2011) report that SOE managers felt pressured by local authorities to provide jobs, and Dong and $\mathrm{Xu}$ (2009) estimate excessive employment in publicly owned industrial firms to $10 \%$ in the early 2000 s. They further report that in the 2003 World Banks second survey, Investment Climate in China, one third of surveyed managers of state firms reported to be over-staffed.

${ }^{21}$ These relationships between size and non-wage benefit provision differ from the arguments in the economics literature which mainly considered the US case (e.g. Rice, 1966; Woodbury, 1983). In the Chinese case, the argument is different because insurance is not acquired on the market, making firm size unrelated to firm bargaining power and the price of insurance.

${ }^{22}$ Beijing, Taiyuan, Shenyang, Harbin, Nanjing, Wuhan, Guangzhou, Chengdu, Xi'an, Dalian, Shanghai, Chongqing, Changchun, and Shanghai.
} 


\subsection{Results}

Table 3 shows the results from estimating Equation (10) for three different specifications and for the two social insurance items. All coefficients are scaled up by 100 to let the point estimates be interpreted as $1.0=$ one percentage point.

The results support the theoretical prediction that firms react to tighter labor markets (a lower unemployment rate and/or a higher vacancy rate) by increased social insurance participation. In the first Column for each insurance item (Columns 1 and 5), the unemployment and vacancy rates are introduced separately. Both estimates have the expected signs, but only the one for the vacancy rate is statistically significant at the ten percent level.

In the remaining columns the unemployment and vacancy rates are combined into the measure of labor market tightness. These estimates all take the expected positive sign and are significant at the five percent level or more. Adding control variables in Columns 3 and 7 only marginally affects the size and significance of the tightness estimate. We can also note that estimates on the control variables measuring market share and firm size have the expected signs, showing that social insurance participation is more common in larger and more powerful firms. The remaining controls are less informative. Regional labor markets dominated by SOEs are not associated with more participation in the pensions and medical programs, but in the unemployment insurance regression the coefficient is statistically significant and of the expected positive sign. The variables measuring the geographical location, i.e. the proximity to large markets and ports, are not statistically significant in any specification and are therefore not reported.

Without firm fixed effects (Columns 2, 3 and 5,6) the tightness parameter is quite large, indicating that a one unit increase in tightness is associated with an increase in insurance participation of 1.5 percentage points for the pension and medical programs, and 0.5 percentage points for the unemployment insurance program. Weighted against the average likelihood of participation in these two programs over the period, these effects correspond to a 1.6 percent greater likelihood of unemployment insurance participation and a 2.7 percent greater likelihood of pension and/or medical insurance participation.

When adding firm fixed effects in Columns 4 and 7, the size of this point estimate is substantially reduced. A likely reason for the drop is that the fixed effects control for some un-observed characteristics drives both insurance participation and the choice of location to more developed (and tighter) labor markets. Of course, attenuation bias could also play a role, indicating that the fixed effects estimate is somewhat understated. 
Table 3: OLS estimation results for labor market tightness and firm participation in social insurance, 2000-2007. The dependent variable is one for firms reporting some non-zero insurance payment in a given year, and otherwise zero.

\begin{tabular}{|c|c|c|c|c|c|c|c|c|}
\hline & \multicolumn{4}{|c|}{ Pension and medical insurance } & \multicolumn{4}{|c|}{ Unemployment insurance } \\
\hline & 1 & 2 & 3 & 4 & 5 & 6 & 7 & 8 \\
\hline Unemployment rate & $\begin{array}{l}-1.607 \\
(2.823)\end{array}$ & & & & $\begin{array}{l}-0.831 \\
(2.824)\end{array}$ & & & \\
\hline Vacancy rate & $\begin{array}{c}0.520^{* * * *} \\
(0.051)\end{array}$ & & & & $\begin{array}{l}0.152^{*} \\
(0.091)\end{array}$ & & & \\
\hline $\begin{array}{l}\text { Labor market } \\
\text { tightness }\end{array}$ & & $\begin{array}{c}1.540 * * * \\
(0.176)\end{array}$ & $\begin{array}{c}1.525^{* * *} \\
(0.215)\end{array}$ & $\begin{array}{c}0.338 * * \\
(0.140)\end{array}$ & & $\begin{array}{c}0.543 * * \\
(0.227)\end{array}$ & $\begin{array}{c}0.561 * * * \\
(0.196)\end{array}$ & $\begin{array}{l}0.270 * \\
(0.147)\end{array}$ \\
\hline SOE share & & & $\begin{array}{l}-8.863 \\
(9.142)\end{array}$ & $\begin{array}{c}1.549 \\
(6.278)\end{array}$ & & & $\begin{array}{l}7.161 * \\
(3.990)\end{array}$ & $\begin{array}{l}-1.958 \\
(4.670)\end{array}$ \\
\hline Log employment & & & $\begin{array}{c}6.467 * * * \\
(0.751)\end{array}$ & $\begin{array}{c}2.722^{* * * *} \\
(0.192)\end{array}$ & & & $\begin{array}{c}7.704 * * * \\
(0.376)\end{array}$ & $\begin{array}{r}3.930^{\text {**** }} \\
(0.304)\end{array}$ \\
\hline Market share & & & $\begin{array}{c}52.49 * * * \\
(8.065)\end{array}$ & $\begin{array}{c}23.28 * * * \\
(5.207)\end{array}$ & & & $\begin{array}{c}40.75 * * * \\
(6.371)\end{array}$ & $\begin{array}{c}9.370 * * \\
(3.552)\end{array}$ \\
\hline $\begin{array}{l}\text { Firm FE } \\
\text { Geographical } \\
\text { controls }\end{array}$ & & & $\mathrm{x}$ & $\mathrm{x}$ & & & $\mathrm{x}$ & $\begin{array}{l}\mathrm{x} \\
\mathrm{x}\end{array}$ \\
\hline Year FE & $\mathrm{x}$ & $\mathrm{x}$ & $\mathrm{x}$ & $\mathrm{x}$ & $\mathrm{x}$ & $\mathrm{x}$ & $\mathrm{x}$ & $\mathrm{x}$ \\
\hline 2-digit industry FE & $\mathrm{x}$ & $\mathrm{x}$ & $\mathrm{x}$ & $\mathrm{x}$ & $\mathrm{x}$ & $\mathrm{x}$ & $\mathrm{x}$ & $\mathrm{x}$ \\
\hline Observations & 793,664 & 793,664 & 793,662 & 793,662 & $1,050,949$ & $1,050,949$ & $1,046,273$ & $1,046,273$ \\
\hline Number of firms & 337,360 & 337,360 & 337,359 & 337,359 & 390,468 & 390,468 & 389,860 & 389,860 \\
\hline
\end{tabular}

Notes: $* * * \mathrm{p}<0.01, * * \mathrm{p}<0.05, * \mathrm{p}<0.1$. Robust standard errors, clustered at the regional level, in parenthesis. Geographical controls are the distance to the closest of China's three large ports, and the distance to the closest of China's 15 largest cities.

Taking the estimates in Columns 4 and 7 at face value, the results show that Chinese firms responded to labor market incentives by increased compliance with social security regulations during the time period analyzed. The size of the estimated effect can be interpreted against the increase in tightness experienced by the average firm. Over the 20002007 period tightness increased by 11 units (4.6 to 15.6), having increased by 7 units ( 8.6 to 15.6) in the latter years of 2004-2007. Using the estimates of 0.34 for the pension and medical programs, and 0.27 for the unemployment insurance, this increase in tightness corresponded to a 2.97 percentage point increase in participation in the unemployment insurance, and a 2.38 percentage point increase in participation in the medical and/or pensions programs. Compared to overall trend in participation rates (see Table 2), the estimates thus suggest that increased labor market tightness could account for about 40 percent of the increase in insurance participation. Considering the crude measure of participation, it should be noted that this type 
of first-step participation (non-zero payments) does not reflect the degree of compliance with payment levels or inequalities in coverage between worker groups within the firm.

\subsection{Robustness checks}

Three robustness checks are used to ascertain the stability of the results in Table 3. The first considers measurement error in the regional unemployment figures due to the exclusion of job-waiters (Columns 1 and 2 of Table 4). To address this concern I keep only the regions that had completed the binggui reform by the early 2000s. In these localities, I expect jobwaiters to have been merged with the unemployment insurance program, making the unemployment numbers more accurate and comparable between regions.

The second robustness check addresses the concern that new firms may have higher participation rates and that firm entries drive the increases in labor market tightness. I balance the panel by only keeping firms with five or more consecutive yearly observations in the unemployment insurance regression and firms with three of more observations in the analysis of the pensions and medical insurance (Columns 3 and 4).

In the third robustness check I include the firms with large combined expenditures on unemployment and labor insurance (Columns 5 and 6), which were previously removed for increased precision.

The point estimates are not sensitive to the three robustness checks. However, the standard errors increase, leading to less precise estimates in the case of the unemployment insurance regression, the binggui sample (p-value 0.14) and when including firms that have high values on the combined expenditures for unemployment and labor insurance (p-value $0.078)$.

As additional notes on robustness, the results are also robust to instead excluding firms that report payment rates below the national standard (as defined by the U.S. SSA, 2010), to using only data for self-governing municipalities and regional capitals, and to using a Probit model in the cases of the specifications without firm fixed-effects. The positive correlation between tightness and participation also holds for regressions using measures of generosity, i.e. the share of social insurance payments to wages. In the interest of space and due to the substantial measurement difficulties associated with some of these tests, results are not reported here..$^{23}$

\footnotetext{
${ }^{23}$ As noted above, a computation of the required payment rate for each firm requires information on contract types, and geographical variation in required payment levels and caps. Moreover, firms are likely to over-report social insurance expenditures and under-report wages to evade taxes (Banister, 2005).
} 
Finally it should be pointed out that reverse causality is not likely to be an issue. In the case of the unemployment insurance, a potential concern could be that workers who receive insurance cover quit their jobs to receive benefits. Arguably, this concern is of little merit because at least one year of continuous firm contributions are required for benefit eligibility, and voluntary unemployment discriminated the worker from benefit receipts.

Table 4: Robustness checks corresponding to the specification in Table 3, columns 4 and 8. Excluding non-binggui regions and balancing the firm panel.

\begin{tabular}{lcccccc}
\hline & \multicolumn{2}{c}{ Binggui regions } & \multicolumn{2}{c}{ Balanced panel } & \multicolumn{2}{c}{ LIS firms } \\
& PM & UI & PM & UI & PM & UI \\
\hline Tightness & $0.413^{* *}$ & 0.294 & $0.310^{* *}$ & $0.210^{*}$ & $0.344^{* * *}$ & $0.256^{*}$ \\
& $(0.172)$ & $(0.159)$ & $(0.144)$ & $(0.131)$ & $(0.149)$ & $(0.146)$ \\
Observations & 586,565 & 768,187 & 607,099 & 463,837 & 909,925 & $1,230,162$ \\
Number of firms & 242,261 & 275,713 & 198,982 & 109,150 & 355,231 & 413,963 \\
\hline
\end{tabular}

Notes: *** $\mathrm{p}<0.01, * * \mathrm{p}<0.05, * \mathrm{p}<0.1$. Robust standard errors, clustered at the regional level, in parenthesis. All estimations are by OLS and include year fixed effects, industry fixed effects at the 2-digit level, and firm fixed effects. Control variables are the SOE share in regional employment, log of firm employment, market share, distance of the prefecture city to the closest of China's three large ports, and the distance to the closest of China's 15 largest cities.

\section{Extensions}

A rather large research literature has considered the issue of segmentation of China's labor market. In these studies, two dimensions have stood out as the main determinants of "labor markets within the labor market", across which employment and compensation patterns fail to equalize. Diversifying the paper's hypothesis over those segments is highly relevant to policy because of its immediate bearing on the understanding of the connection between the transition to a flexible labor market, inequality and implementation of the social insurance system to all tiers of the industrial workforce.

First, segmentation according to ownership stems in large part from the socialist economy. State-controlled firms - in particular State-owned ones - were traditionally prioritized and protected, with workers given higher wages and more secure employment. A second tier of the socialist industrial sector was made up by Collective owned firms which were less protected and with lower wages and endowments (Hussain, 1994). In the past three decades of market reform, a private sector consisting of domestic and foreign-invested firms was allowed to grow. These firms were not allowed to compete freely with the state- 
controlled firms but faced limitations regarding, for example, the choice of product sector and formal access to financial capital (Huang, 2003). The private domestic firms in particular became a second-class of employers, offering less generous work compensation (Dong and Bowles, 2002; Chen et al., 2005).

As noted in the literature review above, some recent studies have pointed to the role of unionization as a driver of social insurance provision of industrial firms (Yao and Zhong, 2010; Lu et al., 2010). The authors interpret their results as the existence of an, albeit weak, bargaining role for unions in the firm's social insurance decision. Such bargaining is not among the official functions of the Chinese union, nor do the papers find a similar positive effect of unionization on wages. The papers however underscore the link between worker compensation, on the one hand, and the institutional proximity between the workplace and the Chinese state on the other.

The second driver of segmentation is the family registration system, hukou. This internal passport system assigns each individual as either urban or rural and also connects him or her to a specific city, town or village. As numerous studies have shown, low-wage and lowsecurity jobs are more common among rural hukou holders in urban areas than among those holding urban equivalents (see for example Knight and Yueh, 2009; Démurger et al., 2009). ${ }^{24}$ Using the 2005 and 2010 samples of the China Urban Labor Study, Giles et al. (2011) show that migrants are 43 percent less likely to have pension contributions through the employer. In a decomposition study of wage differences in urban workplaces, Démurger et al. (2009) compare the explained variance of hukou status as compared to education level. They find that education attainment was the major driver of wage disparities by pre-determining the sector of employment for rural and urban hukou-holders. ${ }^{25}$

For the purpose of structuring the analysis it is, arguably, possible to distinguish between an upper and a lower segment of the industrial labor market, typified by the ownership, workforce education level, and unionization of the firm. To the lower segment I ascribe firms in the private domestic and collective-owned sector: firms with a larger share of low-educated labor, and firms without labor unions. Conversely, the upper segment is defined

\footnotetext{
${ }^{24}$ For example restricted access to certain job positions, quotas and fees applied to enterprises and workers, and labyrinthine systems of permissions.

${ }^{25}$ A related question is the degree of segmentation. Concerning the urban-rural divide, studies have generally found that workers with rural hukou (commonly referred to as "migrant workers") are at least partly restricted from competition with urban hukou holders (see literature review in Knight and Yueh, 2009). Using attitudinal responses from two urban surveys, Knight and Yueh (2009) find that competition between rural and urban segments had increased in the early 2000s.
} 
as state and foreign owned firms: firms with a smaller share of low-educated labor and those that have in-house unions.

Consider first the reasons why we expect the lower segment to have a weaker response; the argument will assume that the labor market tightness measure captures an equally strong labor market signal across the two segments. Consider that the two sectors recruit different types of labor, where the upper segment experiences higher recruitment costs because they recruit workers with higher education and with formal contracts. This difference could, for example, be illustrated theoretically by allowing the recruitment function (3) to differentiate between high or low-skilled labor, to reflect that high skilled labor is more cumbersome to recruit (meaning that $q$ is larger). Assuming higher recruitment costs for skilled workers aligns with findings in the research literature on non-wage compensation behavior of firms (Rice, 1966; Mabry, 1973; Long and Scott, 1982; Woodbury, 1983), and also holds relevance in the Chinese case. The need to attract and retain skills was a common determinant of insurance participation mentioned by each and every firm in Nyland et al.'s (2011) interview study.

However, there are reasons to expect that the lower labor market segment responds more, rather than less, to the labor market signal. This relies on relaxing the assumption that the signal is equally strong across the different worker groups (corresponding to allowing the model's thetas to be diversified across segments). In other words, the regional variation in unemployment and vacancy rates could mask underlying differences across worker groups that the two segments aim to attract. As noted in the introduction, the scenario of a Lewis Turning Point features an increased scarcity of low-wage low-educated workers. If increased tightness over the period reflects this process, we should expect a stronger reaction to the tightness measure among the lower segment firms.

\subsection{Ownership}

Following the standard definition used in the literature (see for example Ayaggari et al., 2010) I define ownership according to the major source of paid-in capital, either as State, Collective, Foreign, or Private. ${ }^{26}$ Figure 4 plots participation rates for the two insurance

\footnotetext{
${ }^{26}$ Paid-in capital is listed from six sources: the state, collective investors, legal entities, individuals, foreign investors and investors from Hong Kong, Macao, and Taiwan. A majority share of capital from state or collective investors is considered as ownership by these two entities. Foreign ownership is defined as majority ownership by either foreign investors or investors from Hong Kong, Macao, or Taiwan. Private ownership is inferred from majority ownership by individuals or by legal entities. This decision rule gives a non-ambiguous answer about ownership for $99 \%$ of the firms, and the remaining $1 \%$ is dropped from the analysis.
} 
variables over time for each of these four ownership sectors. The patterns of participation are similar for both variables, confirming the expected hierarchy in compensation generosity shown in previous literature in the case of wages (for example Dong and Bowles, 2002; Chen et al., 2005). Notably higher participation rates exist among the State owned and Foreigninvested firms compared to the lower rates for the Collective and Private owned sectors. ${ }^{27}$ Recall here that the figure draws upon the unbalanced panel of firms and should be (loosely) interpreted as the average likelihood of coverage for a worker in the four sectors. Because the sectoral composition changes over time due to firm entries and exits it cannot, however, be interpreted as trends in participation among a set number of firms.
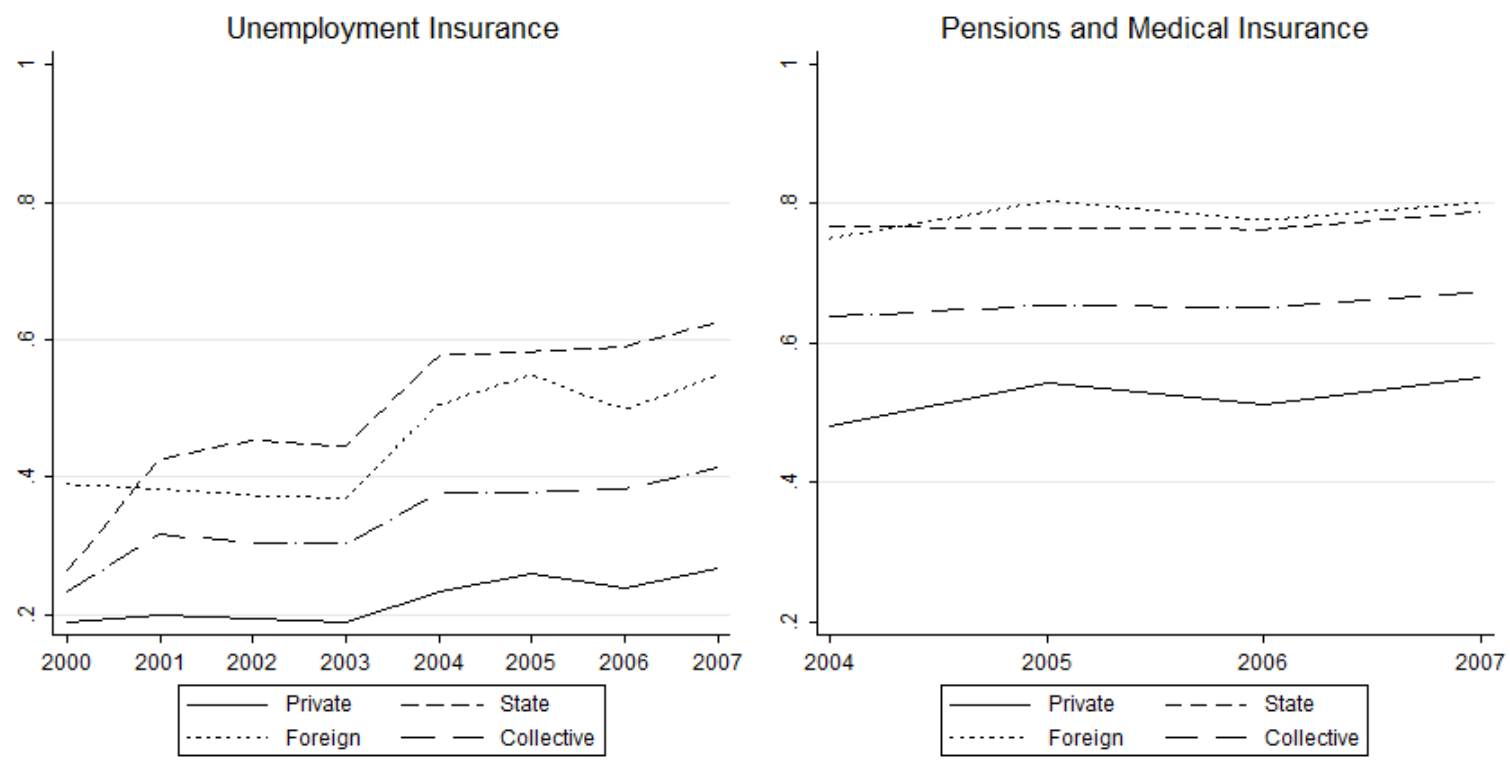

Figure 4: Share of participating firms in the unemployment insurance (left pane) and pension and/or medical insurance (right pane) by ownership sector, 2000-2007.

To analyze if the response to labor market tightness differs across the four ownership sectors I run the most conservative specification of the baseline regression model, that including firm fixed effects (Columns 4 and 8 of Table 3), for each sector separately. The results (see Table 5) show positive and statistically significant estimates for the private and foreign sectors. For the state-controlled sectors, state- and collective owned firms, the estimates are not statistically significant. ${ }^{28}$

\footnotetext{
${ }^{27}$ This pattern however contradicts the finding of Nyland et al. (2006), namely that compliance with social insurance regulations was less stringent in foreign-invested and Hong-Kong-, Macao- and Taiwan-invested firms. As discussed in footnote 10, this result is somewhat cast in doubt because of the sample selection of the audit data sample, and it is also partly retracted by the authors in a later publication (Nyland et al., 2011).

${ }^{28}$ Classification according to registered ownership form does not impact on the results.
} 
Differences across sectors should be interpreted cautiously due to the rather large standard errors for the regression analysis of the two state-controlled sectors. Nevertheless, they indicate that private firms (both domestic and foreign owned) are more responsive to labor market signals in terms of participation in social insurance schemes. This indicates that the State-controlled sectors lag behind in terms of marketization, i.e. efficiency seeking, of labor relations, possibly because of soft budget constraints and/or agency costs.

The positive and significant result for private domestic firms indicates that labor scarcity may indeed be the greater in the worker segment hired by these firms. It also indicates that a tighter labor market could lead to a narrowing of the social insurance inequalities between workers in the state and private domestic sectors. Finally, it is interesting to note that because private domestic firms constitute the fastest growing ownership sector in Chinese industry, the compensation in on the industrial labor market as a whole is likely becoming more responsive to labor market signals.

Table 5: OLS estimates of the effects of labor market tightness on firm provision of unemployment insurance (2000-2007) and pensions and/or medical insurance (2004-2007).

\begin{tabular}{|c|c|c|c|c|c|c|c|c|}
\hline & \multicolumn{2}{|c|}{ State } & \multicolumn{2}{|c|}{ Collective } & \multicolumn{2}{|c|}{ Private } & \multicolumn{2}{|c|}{ Foreign } \\
\hline & PM & UI & PM & UI & PM & UI & PM & UI \\
\hline Tightness & $\begin{array}{c}0.299 \\
(0.337)\end{array}$ & $\begin{array}{l}-0.199 \\
(0.152)\end{array}$ & $\begin{array}{c}0.275 \\
(0.212)\end{array}$ & $\begin{array}{c}0.095 \\
(0.154)\end{array}$ & $\begin{array}{l}0.307 * \\
(0.165)\end{array}$ & $\begin{array}{c}0.290^{* *} \\
(0.137)\end{array}$ & $\begin{array}{c}0.625 * * * \\
(0.128)\end{array}$ & $\begin{array}{c}0.327 * * * \\
(0.112)\end{array}$ \\
\hline $\begin{array}{l}\text { Nr. of } \\
\text { Observations }\end{array}$ & 21,226 & 48,143 & 21,119 & 36,154 & 612,487 & 770,436 & 131,226 & 179,358 \\
\hline Nr. of firms & 12,526 & 23,790 & 14,938 & 23,045 & 272,797 & 309,828 & 55,902 & 62,897 \\
\hline $\begin{array}{l}\text { Notes: } * * * \mathrm{p}< \\
\text { estimations ar } \\
\text { variables inclu } \\
\text { share, distance } \\
\text { China's } 15 \text { lar }\end{array}$ & $\begin{array}{l}\text {,** } \\
\text { OLS } \\
\text { in all }\end{array}$ & $\begin{array}{l}{ }^{*} \mathrm{p}< \\
\text { clude } \\
\text { ssions }\end{array}$ & $\begin{array}{l}\text { Robust } \\
\text { r fixed e } \\
\text { the SOF }\end{array}$ & $\begin{array}{l}\text { ard erro } \\
s \text { and in } \\
\text { e in reg }\end{array}$ & $\begin{array}{l}\text { clustere } \\
\text { try fixe } \\
\text { al empl }\end{array}$ & $\begin{array}{l}\text { the regiona } \\
\text { ects at the } \\
\text { ent, log of }\end{array}$ & $\begin{array}{l}\text { vel, in p } \\
\text { git level } \\
\text { lemploy }\end{array}$ & $\begin{array}{l}\text { ntheses. Al } \\
\text { ontrol } \\
\text { nt, market } \\
\text { closest of }\end{array}$ \\
\hline
\end{tabular}

\subsection{Workforce education level}

Data on the educational attainment for each worker in each firm was collected in the 2004 firm Census, and estimation is made possible by imputing the 2004 values for the same firms and for all other years. This requires dropping the firm fixed effects which will, as noted in the baseline estimation (Table 3) inflate the point estimates. Using a non-parametric method, I construct dummy variables for each quartile of the share of workers with below high school educational attainment. These dummy variables are included in the regression 
together with interaction terms between each quartile of low-educated workers and the tightness parameter.

Table 6 shows the share of participating firms in each insurance program for each quartile of the chosen measure of educational attainment of the workforce. We see that the greater the share of workers with below high school education, the smaller the participation rate in the social insurance programs. This illustrates one facet of the inequality in insurance coverage between workers. It also supports the insight from previous research that higher recruitment and turnover costs for highly educated labor can constitute incentives for more stringent compliance with insurance regulations in some firms.

Table 6: Share of participating firms (\%) in unemployment and pension and/or medical insurance programs by quartile of workers with below high school education in the firm's workforce.

\begin{tabular}{|c|c|c|c|c|}
\hline & $\mathrm{Q} 1$ & Q2 & Q3 & Q4 \\
\hline $\begin{array}{l}\text { Unemployment insurance participation } \\
(2000-2007)\end{array}$ & 40 & 33 & 28 & 24 \\
\hline $\begin{array}{l}\text { Pensions and/or medical insurance participation } \\
(2004-2007)\end{array}$ & 65 & 61 & 59 & 57 \\
\hline
\end{tabular}

Table 7 shows the estimation results for the pension and medical insurance (Column 1) and unemployment insurance (Column 2). The last four rows show that the differences in participation rates across quartiles of low-educated workers shown in Table 6 are statistically significant. The likelihood that a firm participates in either insurance program falls dramatically with the share of low-educated workers.

The interaction terms between tightness and the share of low-educated workers however tells the opposite story. They are all of positive sign and statistically significant, indicating that labor market tightness has affected the pool of labor hired by these firms more strongly, corresponding to the scenario of a growing scarcity of migrant labor ${ }^{29}$ On the other hand, the results do not support the argument that firms with highly-educated labor have been incentivized more by labor market tightness due to the higher recruitment cost per worker. These results are robust to including controls for firm ownership, and to several alternative measures of the human capital distribution in the firm.

\footnotetext{
${ }^{29}$ The result is not likely the consequence of bias from excluding the firm fixed effects. Firms with more educated workforces could exist in more developed (tighter) labor markets and also be more likely to join the social insurance programs, which should cause bias from this source to run in the opposite direction of the results.
} 
Table 7: Social insurance response to labor market tightness by quartiles of the share of workers with below high school educational attainment.

\begin{tabular}{lcc}
\hline & Pensions and Medical Insurance & Unemployment Insurance \\
\hline Tightness & $1.072^{* * *}$ & $0.141^{* * *}$ \\
& $(0.148)$ & $(0.052)$ \\
Tightness * Q2 & $0.334^{* * *}$ & $0.261^{* * *}$ \\
& $(0.116)$ & $(0.066)$ \\
Tightness * Q3 & $0.613^{* * *}$ & $0.331^{* * *}$ \\
& $(0.156)$ & $(0.085)$ \\
Tightness * Q4 & $0.859^{* * *}$ & $0.141^{* * *}$ \\
& $(0.188)$ & $(0.052)$ \\
Q2 & $-9.673^{* * *}$ & $-10.149^{* * *}$ \\
& $(1.675)$ & $(1.392)$ \\
Q3 & $-16.210^{* * *}$ & $-16.672 * * *$ \\
& $(2.478)$ & $(2.095)$ \\
Q4 & $-21.803^{* * *}$ & $-21.240^{* * *}$ \\
& $(2.935)$ & $(2.511)$ \\
& 546,018 & 688,493 \\
Observations & 190,624 & 190,624 \\
Number of firms & &
\end{tabular}

\subsection{Unionization}

To explore the role of unions I use information from the 2004 Census and estimate the baseline model including an interaction term between unionization and tightness. In this year, 41 percent of the firms reported to be unionized, and as is shown in Table 8 below, the participation rate in social insurance was almost twice as high in those workplaces.

Table 8: Share of participating firms in the pension and/or medical insurance and unemployment insurance programs for firms with and without a labor union, 2004.

\begin{tabular}{lcc}
\hline & Pension and Medical Insurance & Unemployment Insurance \\
\hline Unionized & 66 & 39 \\
Non-unionized & 47 & 23 \\
\hline
\end{tabular}

That difference in participation rate is robust to the inclusion of control variables, and fixed effects for year and industry is shown by the large, positive and statistically significant estimate on the un-interacted union variable (see Table 9). This finding confirms the previous 
evidence from Chinese firm-level and individual-level data (Du et al., 2006; Yao and Zhong, 2010; Lu et al., 2010; Giles et al., 2011).

A more novel finding is that the interaction term between unionization and labor market tightness is negative, statistically significant and fairly large in size compared to the estimate on the un-interacted tightness variable. Unionized firms are hence found to have responded less to the labor market conditions than those without unions. This finding aligns with the conclusions from the sections above, namely that the lower segment of the industrial labor market was more forcefully affected by the rise in labor market tightness. It also supports the insight that tightness triggered a convergence between sectors with weaker and stronger government agency.

Together with the other results on firm heterogeneity, the results for unionization compound to show that worker demand is a less important factor in explaining the correlation between tightness and insurance participation. A strong role for demand should have led to the opposite result. If unions leverage the increased demand, the response to tightness should have been greater in the unionized firms. Similarly, stronger bargaining power is expected from highly-educated workers, and also from older workers in the State-controlled sectors. However, reaching a solid conclusion on this question, of course, requires a more precise and comparable measure of labor market tightness.

Table 9: Social insurance response to labor market tightness by firm unionization.

\begin{tabular}{lcc}
\hline & Pensions and Medical Insurance & Unemployment Insurance \\
\hline Tightness & $1.661 * * *$ & $0.618^{* * *}$ \\
& $(0.195)$ & $(0.201)$ \\
Union & $22.670 * * *$ & $17.208 * * *$ \\
& $(1.782)$ & $(1.626)$ \\
& $-0.704 * * *$ & $-0.381 * * *$ \\
Tightness * Union & $(0.124)$ & $(0.075)$ \\
& 593,896 & 773,067 \\
& 216,002 & 224,783 \\
Observations & & \\
Number of firms & &
\end{tabular}




\section{Concluding remarks}

In market systems, firms use incentives to reward workers for mobility and to attract productive personnel. In socialist states, creating such a flexible labor market entails large institutional adjustments, among which is a transfer from a work-unit based entitlement system of social welfare to a portable and flexible social insurance system. The overhaul of the Chinese entitlement system created risk pools for the different new social insurance programs, but the workplace remained responsible for complying with regulations and making payments both to the pooled fund and to workers' individual accounts.

Understanding the drivers of firm compliance is of great importance to the economic security and well-being of China's citizens, who also make up the largest industrial workforce in the world. Successful implementation also holds the promise of a more productive and flexible workforce by providing protection from income shocks and facilitating job transitions. In the Chinese case, the analysis is also closely related to the issue of increasing domestic consumption by removing the main motives for precautionary savings.

This paper aims at furthering our understanding of the social insurance participation decision of Chinese industrial firms by analyzing the role of labor market conditions. In three extensions I also analyze whether the response to this labor market signal differed over labor market segments in terms of ownership, education level of the workforce, and unionization.

The baseline results show that during the 2000-2007 period, the trend of increasing tightness on regional labor markets could explain about half of the increase in participation among medium- and large-size firms. The general insight is thus that firms used non-wage benefits as a means to attract labor in response to market signals, indicating the existence of labor market flexibility and efficiency concerns in the remuneration process. Importantly, this also means that the regulatory enforcement of the new social insurance programs was substantially aided by tighter labor market conditions. Firm responses in terms of rule compliance could therefore work as a catalyst for domestic consumption growth by providing improved income protection as labor grows scarcer when the labor market develops further.

In interpreting the size of this effect, it is however important to remember that the dichotomous measure of participation used in this paper captures only coverage provided to at least some workers in the firm. Internal segmentation of coverage remains outside the scope of the analysis, meaning that the consumption and flexibility response to improved participation is likely smaller than predicted by the large quantitative impact. 
Extending the analysis to firm sub-divisions according to the previous literature on labor market segmentation, and corresponding to the much-studied issue of whether China has reached the Lewis Turning Point, also led to several findings. Participation in social insurance programs was greater in the firm subsets defined as the upper segment of the labor market, firms with more highly-educated workers, under state- and foreign ownership, and having inhouse unions. The response to labor market conditions from the baseline analysis was however found to stem mainly from the other, lower, segment of the labor market, namely firms under private ownership, with more low-educated workers and lacking labor unions.

Why did the lower segment respond more strongly to labor market tightness? The main interpretation is that tightness was more severe for these firms, although it could also reflect weaker attractiveness in terms of other working conditions which make firms "first-hit" by a reduced worker supply.

Finding a more pronounced response to labor market tightness in the sectors where participation is currently the lowest can be considered reassuring from a policy perspective. It suggests that the implementation process of the social security programs will be aided by the expected further tightening of the labor market as China approaches the Lewis Turning Point. This would reflect a convergence between the participation rates in different sectors, in other words, reduced inequality in labor protection. In this context we should recall the incomplete coverage of the dataset. Even though the results suggest that tightness drove a convergence between more and less formalized sectors of the industrial labor market, the least formalized sector, small and informal firms, did not form part of the analysis and remain the hardest to reach by government regulation.

The precision of the results in this paper is limited by the lack of detail in the measurements of both the labor market conditions and the participation behavior of the firm. Future studies could consider more aspects of internal segmentation of coverage in order to further our insights on the relationship between macroeconomic developments and insurance inequality. Accessing more detailed measures on the composition of unemployment and vacancies, both by worker groups and for smaller geographical units, would also be of great value for arriving at more precise answers and policy recommendations.

\section{References}

Ayyagari, Meghana, Demirgüç-Kunt, Asli, Maksimovic, Vojislav, 2010. Formal versus informal finance: evidence from China. Review of Financial Studies 23, 3048-3097.

Banister, Judith, 2005. Manufacturing earnings and compensation in China, Monthly Labor Review, August. 
Brandt, Loren, Van Biesebroeck, Johannes, Zhang, Yifan, 2012. Creative accounting or creative destruction? Firm-level productivity growth in Chinese manufacturing, Journal of Development Economics, 339-351.

Becker, Gary S., 1968. Crime and punishment: An economic approach, Journal of Political Economy 76(2), 169-217.

Chamon, Marcos, Prasad, Eswar, 2010. Why are saving rates of urban households in China rising?, American Economic Journal: Macroeconomics 2, 93-130.

China Daily 2006-12-26, 'Social safety net listed as top concern of urbanites'

China's Social Security White Paper, 2004. China's social security and its policy - Section 2: Unemployment Insurance. White Papers of the Government. http://chineseculture.about.com/library/china/whitepaper/bl2004social03.htm

Dong, Xiao-yuan, Bowles, Paul 2002. Segmentation and discrimination in China's emerging industrial labor market. China Economic Review 13(2-3), 170-196.

Chen, Yi, Démurger, Sylvie, Fournier, Martin, 2005. Earnings differentials and ownership structure in Chinese enterprises. Economic Development and Cultural Change 53(4), 933-958.

Démurger, Sylvie, Gurgand, Marc, Li, Shi, Yue, Ximing, 2009. Migrants as second-class workers in urban China? A decomposition analysis. Journal of Comparative Economics 37(4), 610-628.

Dong, Xiao-yuan, Xu, Lixin, 2009. Labor restructuring in China: Toward a functioning labor market. Journal of Comparative Economics 37(2), 287-305.

Du, Yang, Cai, Fang, Wang, Meiyan, 2006. Marketization and/or informalization: New trends of China's employment in transition, paper prepared for the World Bank Labor Markets Development Program. http://www.cenet.org.cn/userfiles/2009-10-17/20091017195702992.pdf

Du, Yang, 2011. Social protection: a pillar of inclusive growth in China. Slides presented at the UNDP International Policy Center for Inclusive Growth [http://www.ipc-undp.org/conference/ workshop_ig/ppt/social_protection/04-inclusive_growth-_Prof_Du.pdf]

Feng, Jin, He, Lixin, Sato, Hiroshi (2011) Public pension and household saving: Evidence from urban China. Journal of Comparative Economics 39, 470-485.

Fox, Louise, Zhao, Yaohui, 2002. China's labor market reform: Performance and prospects, Background paper for the 2002 Country Economic Memorandum, The World Bank.

Giles, John, Park, Albert, Zhang, Juwei, 2005. What is China's true unemployment rate, China Economic Review 16, 149-170.

Giles John, Wang, Dewen, 2011. Social insurance coverage in urban China. Online Slides [http://wiego.org/sites/wiego.org/files/resources/files/Gilessocial_insurance_coverage_china.pdf]

Huang, Yasheng, 2003. Selling China: Foreign investment during the reform era. Cambridge University Press, New York.

Hussain, Athar, 1994. Social security in present-day China and its reform, The American Economic Review 84, 276-280.

Jiang, Yuexiang, Si, Wen, 2008, Study on workers' condition and employees' benefits in private enterprises in Zhejiang province, Mimeo, College of Economics, Zhejiang University, Hangzhou.

Knight, John, Song, Lina, 2005. Toward a labor market in China. Oxford University Press.

Knight, John, Li, Shi, 2005. Wages, firm profitability and labor market segmentation in urban China. China Economic Review 16, 205-228.

Knight, John, Yueh, Linda, 2009. Segmentation or competition in China's urban labor market. Cambridge Journal of Economics 33(1), 79-94.

Lardy, Nicholas R., 2007. China: Rebalancing Economic Growth. In: Bergsten C. Fred, Cary, Eve (Eds.), The China balance sheet in 2007 and beyond, Center for Strategic and International Studies, Washington D.C.

Long, James E., Scott, Frank A., 1982. The income tax and nonwage compensation, The Review of Economics and Statistics 64, 211-19.

Lu, Zhigang. Song, Shunfeng, 2006. Rural-urban migration and wage determination: The case of Tianjin, China, China Economic Review 17, 337-345.

Lu, Yi, Tao, Zhigang, Wang, Yijiang, 2010. Union effects on performance and employment relations: Evidence from China, China Economic Review 21, 202-10. 
Ma, Xiaoying, Ortolano, Leonard, 2000. Lanham, MD, Rowman \& Littlefield.

Mabry, Bevars, 1973. The economics of fringe benefits, Industrial Relations 12, 95-106.

Mares, Isabela, 1997. Is unemployment insurable? Employers and the development of unemployment insurance, Journal of Public Policy 17, 299-327.

Mares, Isabela, 2003. The sources of business interest in social insurance: Sectoral versus national differences, World Politics 55, 229-58.

New York Times, David Barboza, 2006-04-03, Labor Shortage in China May Lead to Trade Shift.

Nielsen, Ingrid, Smyth, Russell, 2007. Who bears the burden of employer compliance with social security contributions? Evidence from Chinese firm level data, China Economic Review 19, 230-44.

Nyland, Chris, Smyth, Russell, Zhu, Cherrie J., 2006. What determines the extent to which employers will comply with their social security obligations? Evidence from Chinese firm level data, Social Policy \& Administration, 196-214.

Nyland, Chris, Thomson, Bruce S., Zhu, Cherrie, J, 2011. Employer attitudes toward social insurance compliance in Shanghai, China. International Social Security Review 64, 73-98.

OECD, 2005. Labor protection in China: Challenges facing labour offices and social insurance. OECD Social, Employment and Migration Working Papers No. 30.

Prasad, Eswar, 2009. Rebalancing growth in Asia, Finance \& Development, 19-22.

Rice, Robert G., 1966. Skills, earnings, and the growth of wage supplements, American Economic Review 56, 583-93.

Schwartz, Jonathan, 2003. The impact of state capacity on enforcement of environmental policies: the case of China. Journal of Environment and Development 12, 50-81.

Sha, Yinhua, 2007. China's social security system: Present status and issues, NLI Research Institute, Tokyo. http://www.mof.go.jp/pri/research/seminar/20060601/s4_02.pdf

Tang, Kwong-Leung, Ngan, Raymond, 2001. China: developmentalism and social security. International Journal of Social Welfare 10(49), 253-259.

Taylor, Guy, 2011. China's floating migrants: Updates from the $20051 \%$ population sample survey. London School of Economics Migration Studies Center Working Paper No. 2011/07.

The Economist 2008-09-04, Reserve Army of Underemployed.

U.S. Social Security Administration, Social security throughout the world, various country reports: http://www.ssa.gov/policy/docs/progdesc/ssptw/

Vodopivec, Milan, Tong, Minna H., 2008. China: Improving unemployment insurance, World Bank Social Protection Discussion Paper No. 08/20.

http://siteresources.worldbank.org/SOCIALPROTECTION/Resources/SP-Discussionpapers/Labor-Market-DP/0820.pdf.

Wang, Fei-Ling, 2005. Organizing through division and exclusion, Stanford University Press: Stanford, CA.

Social Security White Paper, 2004. China's social security and its policy, http://english.gov.cn/official/2005-07/28/content_18024.htm.

Woodbury, Stephen A., 1983. Substitution between wage and nonwage benefits, American Economic Review 73, 166-82.

Xinhua, 2012-06-03, China approves 5-year plan for social security development.

Yao, Yang, Zhong, Ninghua, 2010. Unions and workers' welfare in Chinese firms, Working Paper No. 10/04, China Center for Economic Research, Beijing. http://en.ccer.edu.cn/download/68241.pdf

Zhang, Sifeng, Zhang, Wenxue, Wang, Lijian, Zhang, Li, 2010. China's migrant workers' social security. Chinese Journal of Population, Resources and Environment 8(2), 3-12 